\title{
Helicobacter Pylori and Gastroduodenal Ulcer Disease
}

\author{
Wolfgang Fischbach, Peter Malfertheiner, Jörg C. Hoffmann, Wolfgang Bolten, \\ Manfred Kist, Sibylle Koletzko
}

\section{SUMMARY}

Background: Helicobacter pylori-associated diseases and gastroduodenal ulcer disease are common conditions of major clinical and economic importance. There is thus a need for a guideline that incorporates the scientific knowledge gained in recent years and that takes specific aspects of the situation in Germany into account with regard to epidemiology, resistance status, diagnostic evaluation, and treatment.

Methods: This level-S3 consensus guideline was developed in accordance with the recommendations of the Association of Scientific Medical Societies in Germany (Arbeitsgemeinschaft der Wissenschaftlichen Medizinischen Fachgesellschaften, AWMF). It was commissioned by the German Association for Digestive and Metabolic Diseases (Deutsche Gesellschaft für Verdauungs- und Stoffwechselkrankheiten, DGVS) and prepared in cooperation with other scientific societies. After search terms were compiled, a systematic,

Medizinische Klinik II und Klinik für Palliativmedizin, Klinikum Aschaffenburg: Prof. Dr. med. Fischbach

Klinik für Gastroenterologie, Hepatologie und Infektiologie, Universitätklinikum Magdeburg: Prof. Dr. med. Malfertheiner

Abteilung für Innere Medizin I, St. Marienund St. Annastiftskran-

kenhaus, Ludwigshafen: PD Dr. med. Hoffmann

Rheumatologie, KlausMiehlke-Klinik, Wiesbaden: Dr. med. Bolten

Institut für Medizinische Mikrobiologie und Hygiene, Nationales Referenzzentrum Helicobacter pylori, Universitätsklinikum Freiburg: Prof. Dr. med.

Kist

Abteilung für Pädiatrische Gastroenterologie und Hepatologie, Dr. von Haunersches Kinderspital, LudwigMaximilians-Universität, München: Prof. Dr. med. Koletzko
IT-supported literature search was performed in the PubMed and Cochrane databases. The search was restricted to articles that appeared in German or English from 2000 onward.

Results: H. pylori infection can be accurately diagnosed either non-invasively (with $\mathrm{a}^{13} \mathrm{C}$-urea breath test or a stool antigen test) or invasively (with a rapid urease test, by histology, or by culture). Gastric and duodenal ulcer and gastric MALT lymphoma are absolute indications for eradication therapy; relative indications include functional dyspepsia, the prevention of gastric cancer in persons at risk, the initiation of long-term treatment with non-steroidal anti-inflammatory drugs (NSAID), and the prior occurrence of gastroduodenal complications with the use of either NSAID or acetylsalicylic acid (ASA). First-line therapy consists of a proton-pump inhibitor (PPI) and clarithromycin combined with either metronidazole or amoxicillin, given for at least one week.

Conclusion: This guideline enables the structured, evidence-based diagnosis and treatment of $\mathrm{H}$. pylori infection and associated conditions, as well as of gastroduodenal ulcer disease.

Key words: Helicobacter pylori, gastric ulcer, duodenal ulcer, guideline

Gite this as: Dtsch Arztebl Int 2009; 106(49): 801-8 DOH: 10.3238/arztebl.2009.0801 fter the (re)discovery of Helicobacter pylori ( $H$. pylori) in 1983 by Warren und Marshall (1), the importance of this organism in gastroduodenal ulcer disease was recognized. In the years that followed, it was also found to play an etiological and pathogenetic role in gastric carcinoma and MALT lymphoma, and to be associated with yet other diseases of the stomach and other organs.

In view of the high frequency of $H$. pylori associated diseases, including gastroduodenal ulcer disease, and their major clinical and socioeconomic importance, an interdisciplinary guideline is needed that will take into account new scientific knowledge on this topic as well as specific considerations for Germany with respect to epidemiology, antibiotic resistance, diagnosis, and treatment. This guideline was developed on the initiative of the German Society for Digestive and Metabolic Diseases (Deutsche Gesellschaft für Verdauungs- und Stoffwechselkrankheiten, DGVS) and in collaboration with other medical societies. It meets the methodological criteria for an evidence-based guideline of level 3 (S3) as defined by the Association of the Scientific Medical Societies in Germany (Arbeitsgemeinschaft der Wissenschaftlichen Medizinischen Fachgesellschaften, AWMF).

In this brief summary, important practical aspects of the epidemiology, diagnostic evaluation, and treatment of $H$. pylori infection are presented, and the indications for its eradication are presented as recommended in the guideline. For further information, the reader is directed to the complete guideline (2), which also contains literature references for some pieces of information whose source is not specified in this article.

\section{Methods}

The organizing committee assembled the expert groups, named the group leaders, and defined seven groups of topics (Box):

- Epidemiology

- Diagnostic evaluation, characterization, resistance, and resistance testing

- Indications for the treatment of $H$. pylori infection in benign disease

- Prevention and treatment of neoplastic diseases of the stomach (marginal zone B-cell lymphoma of MALT type, gastric carcinoma)

- Treatment of $H$. pylori infection 


\section{Guideline development group}

- Guideline directors / organizing committee

- Prof. Dr. W. Fischbach, Aschaffenburg

- Prof. Dr. P. Malfertheiner, Magdeburg

- Topic group I:

Epidemiology

- Prof. Dr. W. E. Schmidt, Bochum (group leader)

- Dr. O. Götze, Bochum (literature search)

- Topic group II:

Diagnostic evaluation, characterization, resistance, and resistance testing

- Prof. Dr. M. Kist, Freiburg (group leader)

- PD Dr. U. Peitz, Münster (group leader)

- PD Dr. A. Timmer, Freiburg (literature search)

- Topic group III:

Indications for the treatment of $\mathrm{H}$. pylori infection in benign disease

- Prof. Dr. P. Layer, Hamburg (group leader)

- Dr. U. Rosien, Hamburg (literature search)

- Topic group IV:

Prevention and treatment of neoplastic diseases of the stomach (marginal zone B-cell lymphoma of MALT type, gastric carcinoma)

- PD Dr. A. Morgner, Dresden (group leader)

- PD Dr. M. Vieth, Bayreuth (group leader)

- Dr. R. Schmelz, Dresden (literature search)

- Dr. J. Bornschein, Magdeburg (literature search)

- Topic group V: Treatment of $\mathrm{H}$. pylori infection

- Prof. Dr. J. Labenz, Siegen (group leader)

- PD Dr. G. Treiber, Homburg/Saar (group leader)

- Dr. J. Maubach, Siegen (literature search)

- Topic group VI:

Special considerations of $\mathrm{H}$. pylori infection in children and adolescents

- Prof. Dr. S. Koletzko, Munich (group leader)

- Dr. A. Schwarzer, Munich (literature search)

- Topic group VII:

Gastroduodenal ulcer diseases that are not associated with $\mathrm{H}$. pylori

- PD Dr. J. Hoffmann, Ludwigshafen (group leader)

- Prof. Dr. C. Prinz, Munich (group leader)

- Dr. J. Preiß, Berlin (literature search)
- Special considerations of $H$. pylori infection in children and adolescents

- Gastroduodenal ulcer diseases that are not associated with $H$. pylori.

A working group was established at the Charité Hospital (Berlin) in the framework of the competence network on chronic inflammatory bowel diseases (members: W. Höhne, J. Hoffmann, J. Preiß). The members of this working group conducted a workshop in which they instructed the participants in the working groups for each of the topics listed above in the proper procedures for choosing search terms and for performing formal literature searches. The searches were carried out in the PubMed and Cochrane databases. They were restricted to publications in English or German that had appeared from 2000 onward (guidelines, systematic reviews, randomized controlled trials, and observational studies). Computer specialists were available to help with the generation of consensussupported dictionaries. The literature search on the chosen terms yielded nearly 20000 articles. The flowchart in Figure 1 shows, by way of illustration, the method that was used to select articles for evaluation in topic group I, “epidemiology.”

Literature searching and supplementation finally yielded 490 selected articles, on the basis of which the group leaders formulated the questions to be addressed. These were then answered in the individual working groups, whereupon the final catalogue of questions was made accessible over the Internet for further processing by all guideline participants (Delphi technique). The group leaders made recommendations for consensus formation on the basis of the answers that had been received to the catalogue of questions, and these recommendations were discussed and revised in the individual working groups on the first day of the concluding consensus conference. Thereafter, the consensus recommendations were submitted to a vote via TED (Tele-Dialog, a tele-voting procedure) (Table 1). In general, the strength of the evidence determined the recommendation grade (Table 2). In some cases where it was thought to be appropriate, however, the consensus conference chose to make the recommendation grade either higher or lower than the strength of the evidence alone might have implied.

\section{Epidemiological situation in Germany}

The Gram-negative bacterium $H$. pylori is an obligate pathogen that colonizes the gastric mucosa and induces a chronic, active type $\mathrm{B}$ gastritis. Conditions that can then arise in the affected tissue include gastroduodenal ulcer disease, distal (non-cardiac) gastric carcinoma, and marginal zone B-cell lymphoma of MALT (mucosa-associated lymphoid tissue) type (A, strong consensus) $(6,7)$.

The epidemiological situation in Germany is characterized by the following:

- An increasing rate of infection with age: $5 \%$ of children and $30 \%$ of adults are infected with $H$. pylori $(3,4)$ 
- A markedly higher infection rate in immigrants (36\% to $86 \%$ )

- A decline in infection rates in recent decades, and also projected into the future ([5]; cohort effect)

- Acquisition of the infection from family members during infancy

- Oral-oral, gastric-oral, and fecal-oral transmission

- Rare recurrent infections in adults (1\% per year).

Vaccination or other preventive measures against $H$. pylori infection are currently unavailable.

\section{Diagnosis of $\mathbf{H}$. pylori infection}

H. pylori infection can be diagnosed either directly (by demonstration of the organism or of fragments of it) or indirectly (measurement of urease activity, antibody detection). Both invasive and non-invasive diagnostic techniques can be used (A, strong consensus). All of the invasive methods are based on endoscopy and the acquisition of biopsy specimens. The various tests have high sensitivity and specificity (Table 3) $(8,9)$, but false-positive and false-negative results remain possible. The former may be due to bacterial colonization of the mouth, pharynx, or stomach, while the latter may be seen in cases of acute upper gastrointestinal bleeding, or when the bacterial colonization is of low density in the aftermath of partial gastric resection or suppressive treatment for $H$. pylori.

\section{Criteria for reliable diagnosis}

The selection of a testing procedure to demonstrate $H$. pylori infection depends on the question being asked, as well as on the indication. Whenever endoscopy is performed, a rapid urease test combined with histology is an option. This procedure involves the taking of one biopsy specimen each from the antrum and corpus of the stomach for the rapid urease test, and then of two further specimens from each of these sites for histology. It thus fulfils the requirement of two positive test results for the diagnosis of $H$. pylori infection (C, strong consensus). The only exception to this rule is duodenal ulcer, for which a single positive test result suffices for therapeutic decision-making, in view of the high prevalence of $H$. pylori in this disease. Histology has the main advantage that it not only reveals the presence of the organism, but also yields information about the distributive pattern and activity of gastritis. Culture is $100 \%$ specific, but relatively cumbersome and expensive, because the biopsy specimens must be sent to a microbiology laboratory in a special nutritive medium. Therefore, culture is usually performed only when resistance testing is needed. If the rapid urease test and the histology yield discordant results, then a urea breath test or stool antigen test for monoclonal antibodies is performed next. Serological tests are an unsuitable basis for therapeutic decision-making, as they cannot differentiate prior infections from persistent infections that require treatment.

Attention should be paid to the minimum temporal interval between any prior suppressive treatment for $H$. pylori and the performance of the test: two weeks after

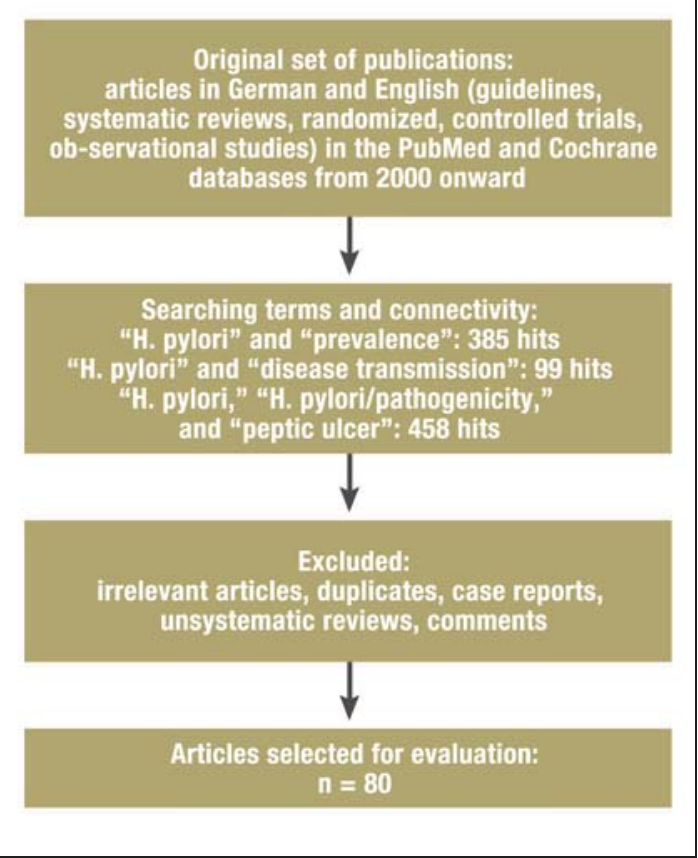

Flowchart:

Systematic literature search on Topic group 1, "epidemiology" (searching terms, connectivity, number of articles in the primary search, articles that were not considered for evaluation, evaluated articles)

\section{TABLE 1}

Classification of consensus strength

\begin{tabular}{|l|l|}
\hline Strong consensus & $\begin{array}{l}\text { Agreement among } \\
>95 \% \text { of participants }\end{array}$ \\
\hline Consensus & $\begin{array}{l}\text { Agreement among } \\
75-95 \% \text { of participants }\end{array}$ \\
\hline Majority decision & $\begin{array}{l}\text { Agreement among } \\
50-75 \% \text { of participants }\end{array}$ \\
\hline No consensus & $\begin{array}{l}\text { Agreement among } \\
<50 \% \text { of participants }\end{array}$ \\
\hline
\end{tabular}

\section{TABLE 2}

Recommendation grade and evidence strength

\begin{tabular}{l|l|l}
$\begin{array}{l}\text { Recommendation } \\
\text { grade }\end{array}$ & $\begin{array}{l}\text { Evidence } \\
\text { strength }\end{array}$ & Comment \\
\hline A & 1 & $\begin{array}{l}\text { Systematic review (with homogeneity) of } \\
\text { randomized controlled trials }\end{array}$ \\
\hline B & $2 \mathrm{a}$ & $\begin{array}{l}\text { Systematic review (with homogeneity) of } \\
\text { cohort studies }\end{array}$ \\
\cline { 2 - 3 } & $2 \mathrm{~b}$ & $\begin{array}{l}\text { Exploratory cohort studies or randomized } \\
\text { controlled trials of low quality }\end{array}$ \\
\hline C & 3 & $\begin{array}{l}\text { Systematic review (with homogeneity) of } \\
\text { case-control studies, or individual case- } \\
\text { control studies }\end{array}$ \\
\hline D & 4 & $\begin{array}{l}\text { Case series and poor-quality case-control } \\
\text { studies }\end{array}$ \\
\cline { 2 - 3 } & 5 & $\begin{array}{l}\text { Expert opinion, or inconsistent or non- } \\
\text { determinative evidence from trials of any } \\
\text { level of evidence quality }\end{array}$ \\
\hline
\end{tabular}




\section{TABLE 3}

Sensitivity and specificity of tests for the detection of H. pylori $(8,9)$

Sensitivity (\%) Specificity (\%)

\begin{tabular}{l|l|l|l}
\hline \multirow{2}{*}{$\begin{array}{l}\text { Invasive } \\
\text { methods }\end{array}$} & Culture & $70-90$ & 100 \\
\cline { 2 - 4 } & Histology & $80-98$ & $90-98$ \\
\cline { 2 - 4 } & Rapid urease test & $90-95$ & $90-95$ \\
\cline { 2 - 4 } & PCR & $90-95$ & $90-95$ \\
\hline $\begin{array}{l}\text { Non-invasive } \\
\text { methods }\end{array}$ & Urea breath test & $85-95$ & $85-95$ \\
\cline { 2 - 4 } & $\begin{array}{l}\text { Monoclonal antibody based } \\
\text { stool antigen test }\end{array}$ & $85-95$ & $85-95$ \\
\cline { 2 - 4 } & $\begin{array}{l}\text { Serum IgG antibody detec- } \\
\text { tion }\end{array}$ & $70-90$ & $70-90$ \\
\hline
\end{tabular}

Necessary steps from the diagnosis to the treatment of H. pylori infection

\section{FIGURE 2}

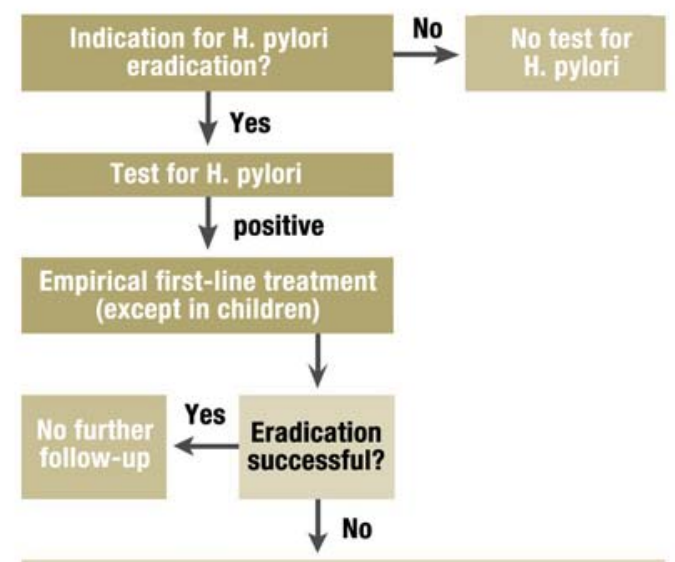

Indication for follow-up endoscopy?

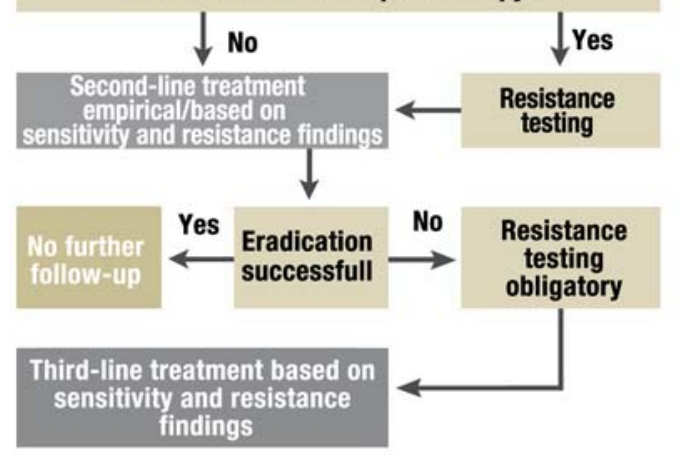

treatment with proton-pump inhibitors and four weeks after eradication therapy or antibiotic treatment for other indications (C, consensus). It is unclear whether $\mathrm{H}_{2}$-receptor antagonists also lower test sensitivity.

\section{From diagnosis to treatment}

The required steps from diagnosis with the methods described above to treatment are summarized in Figure 2.

First, it must be determined whether a diagnostic evaluation for $H$. pylori is indicated and whether eradication therapy would be indicated in case of a positive finding (D, strong consensus). If so, the presence of infection must always be demonstrated before treatment is begun ( $\mathrm{D}$, consensus). Once an infection has been diagnosed, empirical first-line treatment is initiated (except in children). This is possible in Germany because of the favorable resistance situation, which permits us to expect therapeutic success in about $90 \%$ of cases. If successful eradication is confirmed after the necessary minimum interval of time between the end of treatment and the test, routine follow-up testing for $H$. pylori reinfection is not necessary $(\mathrm{B}$, strong consensus). If the bacterium has not been eradicated, the course of further treatment depends on whether followup endoscopy is indicated. If endoscopy is performed, biopsy specimens should be taken for culture and resistance testing (B, majority agreement). This makes it possible for second-line treatment to be given in accordance with the patient's specific pattern of drug resistances and sensitivities. If endoscopy is not performed, second-line treatment is given empirically; if this also fails to eradicate the organism, then endoscopy with biopsy for culture and sensitivity testing is mandatory (B, consensus).

\section{Treatment of $\mathrm{H}$. pylori infection}

The initial treatment of $H$. pylori infection should consist of triple therapy with a proton-pump inhibitor (PPI), clarithromycin, and metronidazole or amoxicillin, given for at least one week (A, strong consensus) (Table 4) (12). Sequential treatment (PPI and amoxicillin for five days, followed by PPI, clarithromycin, and an imidazole derivative for five days) or other types of quadruple therapy are alternative options (A, majority agreement) (20). The data on sequential treatment were, however, obtained in countries with incomparably higher rates of clarithromycin resistance and thus do not necessarily reflect the likelihood of success of this treatment in Germany. Another reason why sequential treatment cannot be generally recommended is the complex mode of administration. It is a fact of practical significance that prior reduction of gastric acidity with a PPI does not endanger the success of $H$. pylori eradication, and thus intravenous antibiotics are not necessary for patients in intensive care units who have bleeding ulcers (A, strong consensus). The rate of severe complications should be less than $5 \%$ (D, consensus), as it indeed is for the first-line protocol outlined here. Nearly all side effects are due solely to the antibiotics used. 
Second-line treatment is given either in accordance with the determined pattern of antibiotic resistances and sensitivities, or else empirically (Figure 2). Figure 3 lists the eradication protocols that are available for empirical second-line treatment (21). Attention should be paid to the possible induction of antibiotic resistance and to any individual intolerances or allergies the patient may have (B, strong consensus). Moreover, accompanying measures that markedly increase the chance of success should be meticulously applied. Third-line treatment should always be initiated by a specialist on the basis of resistance testing.

\section{Special considerations in children and adolescents}

With regard to $H$. pylori infection, children and adults differ in many ways, as discussed in detail in the guideline (2). Two practically important aspects deserve special emphasis here: A "test-and-treat" strategy is inappropriate for symptomatic children and adolescents (C, consensus). Sensitivity testing of gastric biopsy specimens should always be performed before the first treatment is provided, and the particular type of eradication therapy to be used should be chosen according to the results ( $\mathrm{B}$, strong consensus).

\section{Indications for eradication therapy}

The indication for eradication therapy can be absolute, relative, or absent. In the guideline, the position of the recommendation along this continuum is indicated by an auxiliary verb: H. pylori either "must," "should," "may," or "should not” be eradicated. Table 5 contains a summary of the indications together with the corresponding recommendation grades, consensus strengths, and special remarks. There are three major groups of conditions in which a decision about eradication therapy is needed:

- Gastroduodenal diseases

- Use of traditional non-steroidal anti-inflammatory drugs (tNSAIDs) and acetylsalicylic acid (ASA)

- Extragastric diseases.

Some special aspects of the indications listed in Table 5 receive further comment in what follows. The most common and most evidence-based recommendation for eradication therapy is peptic ulcer. Whether the ulcer is present and florid or known from the patient's history, complicated or uncomplicated, gastric or duodenal, H. pylori eradication therapy should always be provided.

In functional dyspepsia, there are two fundamentally different situations that must be distinguished from each other. A "test-and-treat" strategy, i.e., the noninvasive demonstration of $H$. pylori infection followed by eradication therapy without any evaluation of the patient's dyspeptic symptoms by endoscopy, is inappropriate in principle. $H$. pylori eradication therapy can be performed, however, if other causes of dyspepsia have been ruled out by endoscopy. According to the German ELAN study, the number needed to treat (NNT) in this situation is 15 (13).

\section{TABLE 4}

Suitable therapeutic approaches to first-line treatment of $\mathrm{H}$. pylori infection

\begin{tabular}{|c|c|c|c|}
\hline Name & Days & Agents & Dosing \\
\hline \multirow[t]{3}{*}{ Italian TT } & $1-7$ & $\mathrm{PPI}^{*}$ & b.i.d. \\
\hline & $1-7$ & Clarithromycin 250-500 mg & b.i.d. \\
\hline & $1-7$ & Metronidazole 400-500 mg & b.i.d. \\
\hline \multirow[t]{3}{*}{ French TT } & $1-7$ & $\mathrm{PPI}^{*}$ & b.i.d. \\
\hline & $1-7$ & Clarithromycin $500 \mathrm{mg}$ & b.i.d. \\
\hline & $1-7$ & Amoxicillin $1000 \mathrm{mg}$ & b.i.d. \\
\hline \multirow[t]{5}{*}{ Sequential therapy } & $1-5$ & $\mathrm{PPI}^{*}$ & b.i.d. \\
\hline & $1-5$ & Amoxicillin 1000 mg & b.i.d. \\
\hline & $6-10$ & $\mathrm{PPI}^{*}$ & b.i.d. \\
\hline & $6-10$ & Clarithromycin $500 \mathrm{mg}$ & b.i.d. \\
\hline & $6-10$ & Metronidazole $500 \mathrm{mg}$ & b.i.d. \\
\hline \multirow[t]{4}{*}{ Quadruple therapy } & $1-7$ & $\mathrm{PPI}^{*}$ & b.i.d. \\
\hline & $1-7$ & Clarithromycin 250-500 mg & b.i.d. \\
\hline & $1-7$ & Metronidazole $400 \mathrm{mg}$ & b.i.d. \\
\hline & $1-7$ & Amoxicillin $1000 \mathrm{mg}$ & b.i.d. \\
\hline
\end{tabular}

*Proton pump inhibitor (PPI) dose: esomeprazole $20 \mathrm{mg}$, lansoprazole $30 \mathrm{mg}$, omeprazole $20 \mathrm{mg}$, pantoprazole $40 \mathrm{mg}$, rabeprazole $20 \mathrm{mg}$.

TT, triple therapy. Tables 1-4 from Fischbach et al.: S3 guideline on Helicobacter pylori and gastroduodenal ulcer disease of the German Society for Digestive and Metabolic Diseases (Deutsche Gesellschaft für Verdauungs- und Stoffwechselkrankheiten, DGVS). Z Gastroenterol 2009; 47: 68-102 (with the kind permission of Georg Thieme Verlag, Stuttgart/New York.)

\section{FIGURE 3}
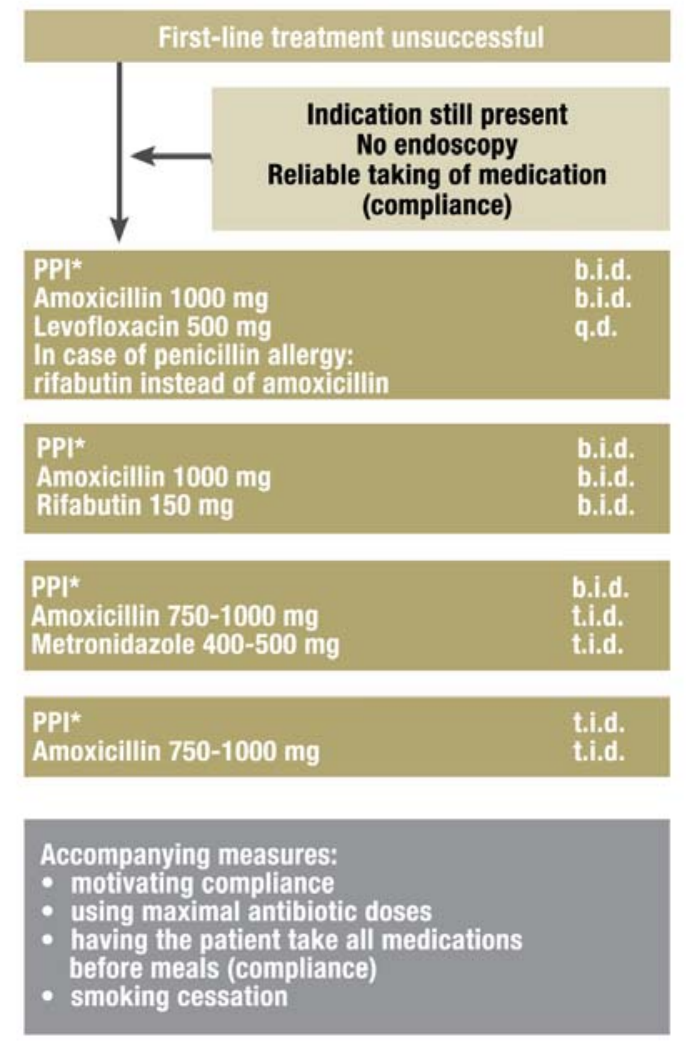

Options for empirical second-line treatment after failure of first-line treatment; duration of treatment, 10 days ( 14 days for dual treatment). *Proton-pump inhibitor (PPI) dose: esomeprazole 20 $\mathrm{mg}$, lansoprazole $30 \mathrm{mg}$, omeprazole 20 mg, pantoprazole $40 \mathrm{mg}$, rabeprazole $20 \mathrm{mg}$ 
Indications for the eradication of $\mathrm{H}$. pylori

\begin{tabular}{|c|c|c|c|c|c|}
\hline & $\begin{array}{l}\text { Absolute } \\
\text { indication } \\
\text { ("must be } \\
\text { eradicated") }\end{array}$ & $\begin{array}{l}\text { Relative } \\
\text { indication } \\
\text { ("should be } \\
\text { eradicated") }\end{array}$ & $\begin{array}{l}\text { Relative } \\
\text { indication } \\
\text { ("may be } \\
\text { eradicated") }\end{array}$ & $\begin{array}{l}\text { No indication } \\
\text { ("should not be } \\
\text { eradicated") }\end{array}$ & $\begin{array}{l}\text { Rcommendation grade, } \\
\text { consensus strength, } \\
\text { remarks }\end{array}$ \\
\hline $\begin{array}{l}\text { Peptic ulcer, whether complicated or } \\
\text { uncomplicated, current or prior }\end{array}$ & $x$ & & & & A (strong consensus) \\
\hline Gastric MALT lymphoma, stage I/II & $x$ & & & & A (strong consensus) \\
\hline $\begin{array}{l}\text { Functional dyspepsia (diagnosis of } \\
\text { exclusion) }\end{array}$ & & $x$ & & & A (strong consensus) \\
\hline $\begin{array}{l}\text { Functional dyspepsia (not investi- } \\
\text { gated, i.e., "test and treat") }\end{array}$ & & & & $x$ & $\mathrm{D}$ (consensus) \\
\hline Asymptomatic gastritis & & & $x$ & & A (consensus) \\
\hline Ménétrier's disease & & & $x$ & & C (strong consensus) \\
\hline Lymphocytic gastritis & & & $x$ & & C (later vote by e-mail poll) \\
\hline $\begin{array}{l}\text { Gastric carcinoma prophylaxis in per- } \\
\text { sons at risk }{ }^{* 1}\end{array}$ & & & $\mathrm{x}$ & & C (strong consensus) \\
\hline $\begin{array}{l}\text { Before long-term treatment with } \\
\text { tNSAIDs in patients with risk factors }{ }^{\star 2}\end{array}$ & & $x$ & & & $\begin{array}{l}\text { A (consensus) } \\
\text { PPI as accompanying } \\
\text { treatment }\end{array}$ \\
\hline $\begin{array}{l}\text { Current long-term treatment with } \\
\text { tNSAIDs }\end{array}$ & & & & $x$ & \\
\hline $\begin{array}{l}\text { Upper gastrointestinal bleeding under } \\
\text { tNSAIDs }\end{array}$ & & & $x$ & & $\begin{array}{l}\text { D (consensus) PPI obligatory } \\
\text { in case tNSAIDs continue to } \\
\text { be used thereafter }\end{array}$ \\
\hline Before long-term treatment with ASA & & & & $x$ & B (consensus) \\
\hline $\begin{array}{l}\text { Upper gastrointestinal bleeding under } \\
\text { ASA }\end{array}$ & & $x$ & & & $\begin{array}{l}\text { B (strong consensus) simul- } \\
\text { taneous long-term treatment } \\
\text { with PPI }\end{array}$ \\
\hline $\begin{array}{l}\text { Idiopathic thrombocytopenic purpura } \\
\text { (ITP) }\end{array}$ & & & $x$ & & B (consensus) \\
\hline $\begin{array}{l}\text { Iron-deficiency anemia of unknown } \\
\text { cause (after adequate diagnostic } \\
\text { evaluation) }\end{array}$ & & & $x$ & & C (consensus) \\
\hline
\end{tabular}

${ }^{1}$ Persons at risk: H.-pylori-positive pan- or corpus-dominant gastritis, first-degree relatives of persons with gastric carcinoma, endoscopic resection of a gastric adenoma or early carcinoma. $\star^{2}$ Risk factors: age over 65 , history of ulcer, co-medication with ASA or steroids, oral anticoagulation

Traditional non-steroidal anti-inflammatory drugs (tNSAIDs) and ASA are recognized ulcerogenic factors that affect therapeutic decision-making when patients taking them simultaneously have an $H$. pylori infection. The considerations include:

- Whether long-term treatment with these drugs (i.e., for longer than 4 weeks) is planned or is already in progress

- Whether there are any additional risk factors for gastrointestinal side effects (Table 5)

- Whether the patient is taking tNSAIDs, ASA, or both

- Whether these medications have already caused complications, such as upper gastrointestinal bleeding.

Treating the patient with a PPI in addition to eradicating $H$. pylori is considered to have a greater preventive effect than $H$. pylori eradication alone and is indicated ("may" or "should" be performed) in certain situations that are listed in Table 5.

\section{New scientific knowledge since issuance of the guideline}

The guideline contains an optional recommendation for $H$. pylori eradication for the prevention of gastric carcinoma in persons at risk. The latter category includes patients with pan- or corpus-dominant gastritis and firstdegree relatives of patients with gastric carcinoma. The cancer-preventing effect of bacterial eradication is greater the earlier the treatment is provided. Once atrophy or intestinal metaplasia has developed, a point of no return may have been reached. Nonetheless, in a randomized trial in Japan, $H$. pylori eradication was also found to prevent the development of metachronic 
carcinoma to a significant extent in patients who had undergone endoscopic resection of an early gastric carcinoma (odds ratio 0.353, 95\% confidence interval $0.161-0.775)(24)$.

The guideline contains a recommendation that accompanying PPI medication should be given to patients taking ASA and clopidogrel simultaneously, because this combination has been shown to increase the risk of gastrointestinal hemorrhage. This recommendation, however, needs to be modified in the light of more recent data. Two retrospective cohort studies published in 2009 provide evidence that the combination of clopidogrel and PPI's elevates cardiovascular risk $(25, \mathrm{e} 1)$. In view of this finding, and with the approval of the European Medicines Agency (EMEA), a "red-hand letter" (urgent safety information) was sent out, stating that "the product information for all clopidogrel-containing medicines should be amended to discourage concomitant use of PPI and clopidogrelcontaining medicines unless absolutely necessary.” The theoretical explanation for this finding may lie in the fact that one of these two substances is activated, and the other metabolized, by the same cytochrome P450 subtype (CYP2C19). Nonetheless, two of three posthoc analyses of data from randomized studies (e2-e5) have failed to show any negative effect of PPI's. The decision whether to use a PPI in a patient taking clopidogrel should thus be made judiciously and on the basis of the patient's individual gastrointestinal risk. A joint position statement on this issue from gastroenterologists and cardiologists would be desirable, in view of the importance of the problem and the large number of cardiac patients affected by it.

\section{Conflict of interest statement}

Prof. Fischbach has received lecture honoraria from the Abbott, SanofiAventis, AstraZeneca, Nycomed, Falk, Pfizer, and Norgine companies. Dr. Bolten has received fees for acting as a consultant, as well as lecture honoraria, from the Pfizer, MDS, and AstraZeneca companies.

Prof. Kist has received financial support in the setting of the "ResiNet" study from Nycomed Deutschland GmbH.

Prof. Malfertheiner has received financial support for lecturing activities from the Abbott, AstraZeneca, and Nycomed companies as well as support for research projects from the AstraZeneca, Axcan, Nycomed, and Novartis companies.

PD Dr. Hoffmann owns shares in Siemens, is a consultant for Essex, and has received lecture honoraria from the Abbott, Esai, Essex, and Falk companies. Prof. Koletzko has received financial support for research from the Oxoid Ltd. Hampshire, AstraZeneca, and Wedel companies. She has received fees for acting as a consultant for AstraZeneca as well as lecture honoraria from the AstraZeneca and Wedel companies.

Manuscript submitted on 20 April 2009, revised version accepted on 27 October 2009.

Translated from the original German by Ethan Taub, M.D.

\section{REFERENCES}

1. Warren JR, Marshall BJ: Unidentified curved bacilli in the stomach of patients with gastritis and peptic ulceration. Lancet 1984; 1: 1311-5.

2. Fischbach W, Malfertheiner P, Hoffmann JC, et al.: S3-Leitlinie „Helicobacter pylori und gastroduodenale Ulkuskrankheit" der Deutschen Gesellschaft für Verdauungs- und Stoffwechselkrankheiten (DGVS). In Zusammenarbeit mit der Deutschen Gesellschaft für Hygiene und Mikrobiologie, Gesellschaft für Pädiatrische Gastroenterologie und Ernährung e.V. und der
Deutschen Gesellschaft für Rheumatologie - AWMF-Register-Nr. 021/001. Z Gastroenterol 2009; 47: 68-102. An English version is currently in print ( $Z$ Gastroenterol, puplication expected for December 2009)

3. Grimm W, Fischbach W: Helicobacter pylori infection in children and juveniles: an epidemiological study on prevalence, socioeconomic factors and symptoms. Dtsch Med Wochenschr 2003; 128: 1878-83.

4. Brenner H, Weyermann M, Rothenbacher D: Clustering of Helicobacter pylori infection in couples: differences between highand low-prevalence population groups. Ann Epidemiol 2006; 16: 516-20.

5. Parsonnet J: The incidence of Helicobacter pylori infection. Aliment Pharmacol Ther 1995; 9 Suppl 2: 45-51.

6. Forman D, Newell DG, Fullerton F, et al.: Association between infection with Helicobacter pylori and risk of gastric cancer: evidence from a prospective investigation. BMJ 1991; 302: 1302-5.

7. Parsonnet J, Hansen S, Rodriguez L, et al.: Helicobacter pylori infection and gastric lymphoma. N Engl J Med 1994; 330: 1267-71.

8. Cutler AF, Havstad S, Ma CK, Blaser MJ, Perez-Perez Gl, Schubert TT: Accuracy of invasive and noninvasive tests to diagnose Helicobacter pylori infection. Gastroenterology 1995; 109: 136-41.

9. Thijs JC, van Zwet AA, Thijs WJ, Oey HB, Karrenbeld A, Stellaard F, et al.: Diagnostic tests for Helicobacter pylori: a prospective evaluation of their accuracy, without selecting a single test as the gold standard. Am J Gastroenterol 1996; 91: 2125-9.

10. Ford AC, Delaney BC, Forman D, Moayyedi P: Eradication therapy for peptic ulcer disease in Helicobacter pylori positive patients. Cochrane Database Syst Rev 2006; (2): CD003840.

11. Leodolter A, Kulig M, Brasch H, Meyer-Sabellek W, Willich SN, Malfertheiner P: A meta-analysis comparing eradication, healing and relapse rates in patients with Helicobacter pylori-associated gastric or duodenal ulcer. Aliment Pharmacol Ther 2001; 15 : 1949-58.

12. Malfertheiner P, Megraud F, O'Morain C, Bazzoli F, El Omar E, Graham D, et al. Current concepts in the management of Helicobacter pylori infection: the Maastricht III Consensus Report. Gut 2007; 56: 772-81.

13. Malfertheiner $P$, Layer $P$, Fischbach W, Mössner J: Helicobacte pylori eradication is beneficial in the treatment of functional dyspepsia. Alimentary pharmacology \& therapeutics 2003; 18 : 615-25.

14. Franchini M, Criciani M, Mengoli C, et al.: Effect of Helicobacter pylori eradication on platelet count in idiopathic thrombocytopenic purpura: a sytematic review and meta-analysis. J Antimicrob Chemother 2007; 60: 237-46.

15. Chen LH, Luo HS: Effects of $H$. pylori therapy on erythrocytic and iron parameters in iron deficiency anemia patients with $\mathrm{H}$. pylori-positive chronic gastritis. World J Gastroenterol 2007; 13: 5380-3.

16. Fischbach W, Goebeler-Kolve ME, Dragosics B, Greiner A, Stolte $\mathrm{M}$ : Long term outcome of patients with gastric marginal zone $B$ cell lymphoma of mucosa associated lymphoid tissue (MALT) following exclusive Helicobacter pylori eradication therapy: experience from a large prospective series. Gut 2004; 53: 34-7.

17. Fischbach W, Goebeler ME, Ruskone-Fourmestraux A, et al.: Most patients with minimal histological residuals of gastric MALT Iymphoma after successful eradication of Helicobacter pylori can be managed safely by a watch and wait strategy: experience from a large international series. Gut 2007; 56: 1685-7.

18. WHO/IARC: Infection with Helicobacter pylori. IARC Monogr Eval Carcinog Risks Hum 1994; 61: 177-240. 
19. Forman D, Graham DY: Review article: impact of Helicobacter pylori on society-role for a strategy of "search and eradicate". Aliment Pharmacol Ther 2004; 19 (Suppl1): 17-21.

20. Zullo A, De Francesco V, et al.: The sequential therapy regimen for Helicobacter pylori eradication: a pooled-data analysis. Gut 2007; 56: 1353-7.

21. Gisbert JP, Morena F: Systematic review and meta-analysis: levofloxacin-based rescue regimens after Helicobacter pylori treatment failure. Aliment Pharmacol Ther 2006; 23: 35-44.

22. Hooper $L$, Brown TJ, Elliott $R$, et al.: The effectiveness of five strategies for the prevention of gastrointestinal toxicity induced by non-steroidal anti-inflammatory drugs: systematic review. BMJ 2004; 329: 948.

23. Kearney PM, Baigent C, Godwin J, et al.: Do selective cyclooxygenase-2 inhibitors and traditional non-steroidal antiinflammatory drugs increase the risk of atherothrombosis? Meta-analysis of randomised trials. BMJ 2006; 332: 1302-8.

24. Fukase K, Kato M, Kikuchi A, et al.: Effect of eradication of Helicobacter pylori on the incidence of metachronous gastric carcinoma after endoscopic resection of early gastric cancer: an open-label, randomised controlled trial. Lancet 2008; 372: 392-7.

\section{Corresponding author}

Prof. Dr. med. Wolfgang Fischbach

Medizinische Klinik II und Klinik für Palliativmedizin

Klinikum Aschaffenburg,

Akad. Lehrkrankenhaus der Universität Würzburg

Am Hasenkopf, 63739 Aschaffenburg, Germany

med2-aschaffenburg@t-online.de

For e-references please refer to:

www.aerzteblatt-international.de/ref4909 


\section{CLINICAL PRACTICE GUIDELINE}

\section{Helicobacter Pylori and Gastroduodenal Ulcer Disease}

Wolfgang Fischbach, Peter Malfertheiner, Jörg C. Hoffmann, Wolfgang Bolten, Manfred Kist, Sibylle Koletzkoe

\section{E-REFERENCES}

1. Ho PM, Maddox TM, Wang L, et al.: Risk of Adverse Outcomes Associated With Concomitant Use of Clopidogrel and Proton Pump Inhibitors Following Acute Coronary Syndrome. JAMA 2009; 301: 937-44.

2. Juurlink DN, Gomes T, Ko DT, et al.: A population-based study of the drug interaction between proton pump inhibitors and clopidogrel. CMAJ 2009; 180: 713-8.

3. Simon T, Verstuyft C, Mary-Kause M, et al.: Genetic determinants of response to clopidogrel and cardiovascular events. N Engl J Med 2009; 360: 363-75.

4. Zairis M, Patsourakos N, Makrygiannis S, et al.: The impact of oral proton pump inhibitors on the effectiveness of combined aspirin and clopidogrel drug therapy during the first year after elective coronary stenting. Eur Heart J 2008; 29(Suppl): 134.

5. Dunn SP, Macualay TE, Brennan DM, et al.: Baseline proton pump inhibitor use is asscociated with increased cardiovascular events with and without the use of clopidogrel in the CREDO trial. Circulation 2008; 118: S815 